National Marine

Fisheries Service

NOAA
Fishery Bulletin

a established in 1881 a
Spencer F. Baird

First U.S. Commissione of Fisheries and founde of Fishery Bulletin

\begin{abstract}
The fishing grounds of the Hawaii-based longline fleet span over 13 million $\mathrm{km}^{2}$ in the central North Pacific Ocean. We investigated over 20 years of commercial fishery logbook data and independent observer data to gain an understanding of the variation in magnitude and composition of the fleet's catch on both intra- and interannual scales. We found that the fishery follows a quarterly geographic migration and that the fishery has expanded over time with a 5 -fold increase in effort and a spatial expansion primarily to the northeast of Hawaii during the third quarter of the year. The World Ocean Atlas and ocean reanalysis data indicate that waters to the northeast of Hawaii are a particularly effective fishing ground because of the vertical overlap of preferred thermal habitat and fishing gear. Furthermore, we found that the Hawaii-based fleet faced little international competition in this region. The expansion of the fishery has also affected catch composition, resulting in discard rates that exceed target catch rates. Understanding how catch varies as a result of oceanographic variability and fleet movement can lead to a more efficient, resilient, and cost-effective fishery.
\end{abstract}

Manuscript submitted 6 July 2017. Manuscript accepted 12 April 2018. Fish. Bull. 116:228-239 (2018). Online publication date: 24 May 2018. doi: 10.7755/FB.116.3-4.2.

The views and opinions expressed or implied in this article are those of the author (or authors) and do not necessarily reflect the position of the National Marine Fisheries Service, NOAA.

\title{
Synergy among oceanographic variability, fishery expansion, and longline catch composition in the central North Pacific Ocean
}

\author{
Phoebe A. Woodworth-Jefcoats (contact author) ${ }^{1,2}$ \\ Jeffrey J. Polovina ${ }^{1}$ \\ Jeffrey C. Drazen ${ }^{2}$ \\ Email address for contact author: phoebe.woodworth-jefcoats@noaa.gov \\ 1 Ecosystem Sciences Division \\ Pacific Islands Fisheries Science Center \\ National Marine Fisheries Service, NOAA \\ 1845 Wasp Boulevard, Building 176 \\ Honolulu, Hawaii 96818 \\ 2 Department of Oceanography \\ School of Ocean and Earth Science and Technology \\ University of Hawaii at Manoa \\ 1000 Pope Road \\ Marine Science Building \\ Honolulu, Hawaii 96822
}

The Hawaii-based longline fishery is among the most economically valuable fisheries in the United States, ranked $6^{\text {th }}$ in $2015\left(\mathrm{NMFS}^{1}\right)$. Its footprint spans over 13 million $\mathrm{km}^{2}$ in the central North Pacific Ocean, ranging from the dateline to $120^{\circ} \mathrm{W}$ and from equatorial waters to roughly $40^{\circ} \mathrm{N}$. The Hawaii-based longline fleet includes 2 fisheries: a shallowset fishery targeting swordfish $(X i$ phias gladius) and a deep-set fishery targeting bigeye tuna (Thunnus obesus). The deep-set fishery is the dominant fishery; both effort and catch (magnitude and value) are an order of magnitude greater than that of the shallow-set fishery $\left(\mathrm{NMFS}^{2}\right)$. For

${ }^{1}$ NMFS (National Marine Fisheries Service). 2016. Total commercial fishery landings at major U.S. ports summarized by year and ranked by dollar value. Fisheries Statistics Division, NMFS. [Data available at website, accessed October 2016.]

2 NMFS (National Marine Fisheries Service). 2016. Annual commercial landing statistics. Fisheries Statistics Divi- this reason, we focused on the deepset fishery in our study.

The deep-set fishery operates largely during the day (Bigelow et al., 2006). Hooks are primarily set between 100 and $400 \mathrm{~m}$ below the surface, and the median hook depth is $250 \mathrm{~m}$ (Boggs, 1992; Bigelow et al., 2006). This depth range coincides with the daytime vertical habitat of bigeye tuna; tagging data indicate that fish of this species spend much of the day 200-400 m below the surface (Boggs, 1992; Ward and Myers, 2005a; Howell et al., 2010) in waters with a temperature range of $8-14^{\circ} \mathrm{C}$ (Howell et al., 2010) and oxygen concentrations over $1.0 \mathrm{~mL} / \mathrm{L}$ (Boggs, 1992; Lehodey et al., 2010).

Although bigeye tuna are the target of the deep-set fishery, the catch also includes a number of other species, some of which are also of commercial value. These commercially valuable, nontarget species include

sion, NMFS. [Data available from website, accessed October 2016.] 
dolphinfish (Coryphaena hippurus), also known as mahi mahi; yellowfin tuna (Thunnus albacares); striped marlin (Kajikia audax); sickle pomfret (Taractichthys steindachneri); and opah (Lampris guttatus). This fishery also catches but discards several noncommercial species, such as the longnose lancetfish (Alepisaurus ferox) and snake mackerel (Gempylus serpens). Recent studies have noted increased catch rates of these noncommercial species concurrent with declines in the catch rate for target species. These changes have been attributed to increasing fishing effort (Ward and Myers, 2005b; Polovina et al., 2009) and prey release of the often smaller, noncommercial fish as larger target species are removed (Polovina and Woodworth-Jefcoats, 2013). These studies support the previous finding that longline fisheries function as a keystone predator in the central North Pacific Ocean (Kitchell et al., 2002).

Despite spanning millions of square kilometers, pelagic fisheries have often been examined as a spatial aggregate (e.g., Cox et al., 2002; Kitchell et al., 2002; Sibert et al., 2006). Previous studies of the Hawaiibased longline fishery, for example, have used spatially averaged trends focused on the core region of the fishery's operating area $\left(12-27^{\circ} \mathrm{N}\right.$; Polovina et al., 2009; Polovina and Woodworth-Jefcoats, 2013). Shifting spatial patterns in fishing effort and the influence these changes may have on catch in the central North Pacific Ocean are under-explored in the primary literature (although see Gilman et al., 2012; Walsh and Brodziak, 2015). Additionally, the effect that international competition has had on the movement of the Hawaii-based fleet has not been explored. In this study, we aimed to determine how both the changing spatial footprint of the fishery and oceanographic variability have influenced catch magnitude and composition, the understanding of which is essential for ensuring a sustainable and cost-effective fishery.

\section{Materials and method}

\section{Materials}

We used both logbook and observer records in this study. Logbook data are reported by fishing vessel masters and contain records of all hooks set (time, date, and location), as well as all commercially valuable catch. Observer data cover an average of roughly $17 \%$ of the fishing effort in the study period and contain records of all hooks set (time, date, and location), as well as all catch, regardless of commercial value. The distribution of observer data correlates well with that of the logbook data (Suppl. Fig. 1), and taken together the 2 data sets provide a robust measure of both fishing effort and catch from 1995 through 2015. Logbook data are complete through 2015 and observer data through 2014. We used all deep-set fishery data, which span the area of $16^{\circ} \mathrm{S}-42^{\circ} \mathrm{N}$ and $179-120^{\circ} \mathrm{W}$. We defined deep sets as those with $\geq 10$ hooks/float (Polovina et al., 2009; Polovina and Woodworth-Jefcoats, 2013).
Logbook data are collected by the Pacific Islands Fisheries Science Center. Observer data are collected by the Pacific Islands Regional Office.

We used publicly available data for longline effort from the Western and Central Pacific Fisheries Commission (WCPFC, data available at website) and the Inter-American Tropical Tuna Commission (IATTC, data available at website) to place Hawaii-based effort in an international context. These data are available at a $5^{\circ} \times 5^{\circ}$ horizontal and a monthly temporal resolution through 2014. The WCPFC provides data for areas west of $150^{\circ} \mathrm{W}$, and the IATTC provides data for areas east of $150^{\circ} \mathrm{W}$. This $150^{\circ} \mathrm{W}$ boundary divides the 2 fishing convention areas of the Hawaii-based fishery.

Global Ocean Data Assimilation System (GODAS) reanalysis data (Saha et al., 2006) provided modeled monthly temperature at depth across the fishing grounds for the entire period studied. The GODAS data used in this study were provided by the Physical Sciences Division of the NOAA Earth System Research Laboratory in Boulder, Colorado, and were downloaded from the Asia Pacific Data Research Center's OPeNDAP server (website). World Ocean Atlas 2013 (WOA13) data (Garcia et al., 2013) provided a 3-dimensional climatological reference of oxygen concentration. The WOA13 oxygen data were downloaded from the National Centers for Environmental Information's OPeNDAP server (website). Both the GODAS and WOA13 data sets are based on in situ observations such as those from Argo floats (Saha et al., 2006) and discrete water samples (Garcia et al., 2013).

\section{Methods}

All data (fishery and environmental), except those from the WCPFC and IATTC, were transformed into a common $1^{\circ} \times 1^{\circ}$ grid matching that of the WOA13 data. The GODAS data were changed from their native $0.33^{\circ} \times 1.00^{\circ}$ resolution by using nearest coordinate regridding. In this study, we examined data at regional and quarterly resolutions (e.g., quarter 1 represents January, February, and March). The Ferret program (NOAA's Pacific Marine Environmental Laboratory, Seattle, WA, website) was used for regridding data.

We assessed several measures of catch magnitude and composition, all in terms of numbers of fish caught as opposed to weight of fish. Catch rates were measured as catch per unit of effort (CPUE), which we defined as the number of fish caught per 1000 hooks set. We focused primarily on catch rates of the target species, bigeye tuna, and on the primary bycatch species, longnose lancetfish. For our assessment of catch composition, we used the 21 most commonly caught species identified by Polovina and Woodworth-Jefcoats (2013). We also followed their method for measuring discard rate (measured as the ratio of catch of longnose lancetfish, snake mackerel, pelagic stingray (Pteroplatytrygon violacea), and $95 \%$ of sharks to total catch).

We defined preferred thermal habitat for bigeye tuna as waters with temperatures of $8-14^{\circ} \mathrm{C}$. Tag- 


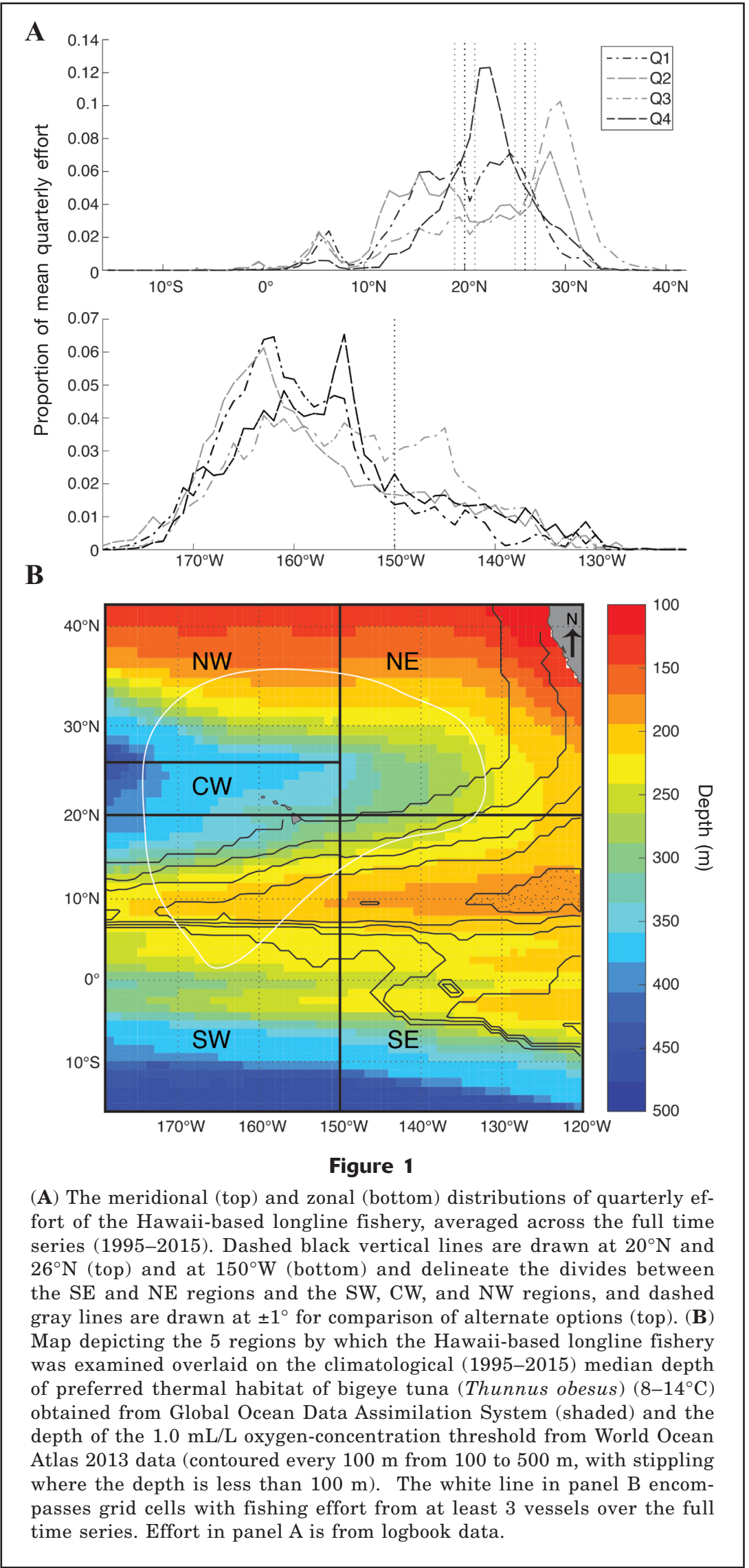

ging data from Howell et al. (2010) indicate that when bigeye tuna are at depth during the daytime, which is when the fishery for bigeye tuna operates, they are primarily in waters within this thermal range. The GODAS data were used to determine the minimum, maximum, and median depths of preferred thermal habitat of bigeye tuna in 2 ways: 1 ) these depths were determined for all grid cells (each $1^{\circ} \times 1^{\circ}$ ) with fishing effort at any point in the time series; 2) quarterly GODAS data were weighted by the number of hooks set in each grid cell during each quarter. We then used standard linear regression to evaluate whether there were significant $(P<0.05)$ linear trends in both unweighted and weighted median depths of preferred thermal habitat. Where significant trends were found, we used linear regression to determine how the depth of preferred thermal habitat changed over the years studied.

\section{Results}

\section{Fishing effort}

Seasonal variability The Hawaii-based longline fishery exhibited strong seasonal movement during the period studied, 1995-2015. Figure 1A shows the temporally averaged meridional and zonal distribution of effort (number of hooks set) each quarter. On the basis of this distribution, as well as the $150^{\circ} \mathrm{W}$ boundary between the 2 fishing convention areas of the Hawaii-based fishing grounds, we divided the fishery into the 5 regions shown in Figure 1B: northeast (NE); northwest $(\mathrm{NW})$; central west (CW); southwest (SW); and southeast (SE). Together, Figures $1 \mathrm{~A}$ and 2 show the movement of the fishery by quarter throughout the year. In the first quarter of the year, most of the effort took place in the SW region north of $10^{\circ} \mathrm{N}$ and in the $\mathrm{CW}$ region. During the second quarter, effort was concentrated in the SW and NW regions. The fishery then underwent a large geographic shift in the third quarter, and most of its effort was directed within the NE region. Effort occurred closest to Hawaii in the $\mathrm{CW}$ region during the fourth quarter. 


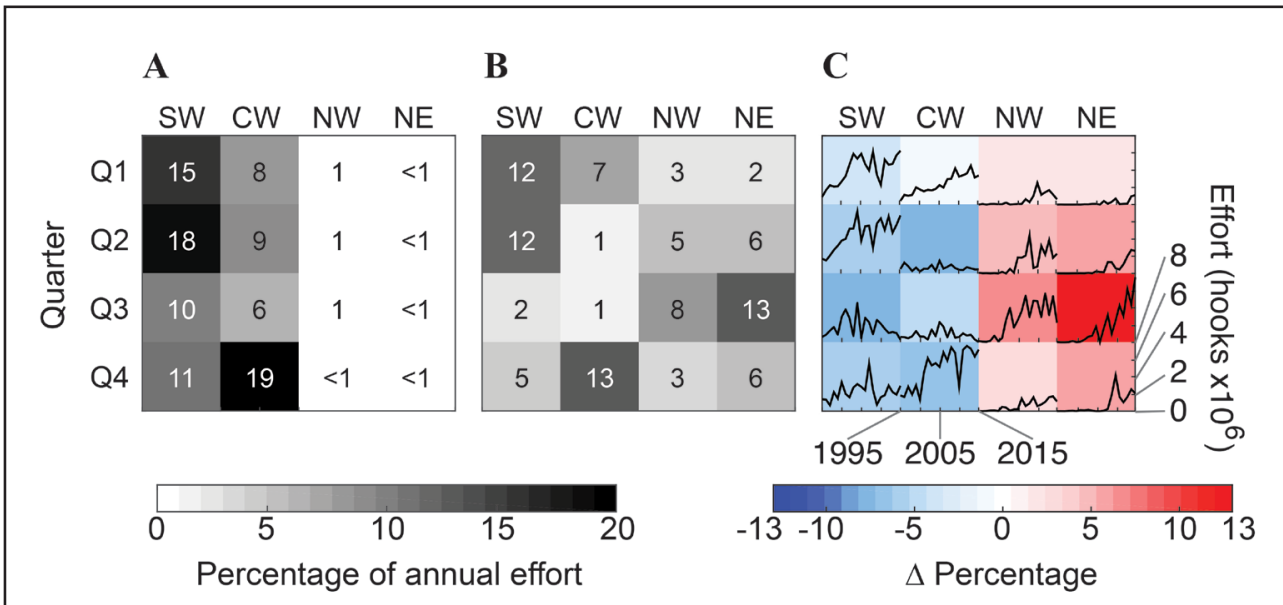

Figure 2

The mean percentages of total annual effort that occurred in each quarter and region at the (A) beginning (1995-1997) and (B) end (2013-2015) of the time series from logbook data examined in this study of the Hawaii-based longline fishery. (C) The change in the percentage of total annual effort that occurred in each quarter and region is shaded in color and overlaid with the total annual effort set in each region and quarter in black. Four regions were used in these analyses: southwest (SW); central west (CW); northwest (NW); and northeast (NE).

There was virtually no fishing effort in the SE region; therefore, it was not included in our analysis.

Interannual variability In 1995 , nearly all (97.1\%) of the Hawaii-based longline effort occurred west of $150^{\circ} \mathrm{W}$ and south of $26^{\circ} \mathrm{N}$ in the $\mathrm{CW}$ and SW regions. Over time, the fishery expanded, and in $2015,41.3 \%$ of the longline fishing effort occurred either north of $26^{\circ} \mathrm{N}$ or east of $150^{\circ} \mathrm{W}$ in the NW and NE regions. Total effort also increased; the total number of hooks set increased steadily from nearly 8.4 million in 1995 to over 47 million in 2015. This increase in fishing effort was greatest in the NE region (Fig. 2). Time series of total effort in each region and quarter (Fig. 2) show that effort increased in the CW and SW regions until about 2004. After this time, and with the exception of the CW region in the first quarter, effort in these regions has remained roughly stable, whereas effort in the NW and $\mathrm{NE}$ regions increased steadily.

Fishery expansion is detailed in Figure 2. It shows that, over the past 21 years, the geographic focus of the fishery changed substantially. Across all quarters, the proportion of total annual effort in the SW and CW regions declined by about $1-8 \%$. At the same time, the proportion of total annual effort in both northern regions increased by $2-13 \%$, with a strong maximum in the $\mathrm{NE}$ region during the third quarter (13\% versus $7 \%$, the next closest value).

International competition The ratio of Hawaii-based effort to international effort varied by region (Suppl. Fig. 2). Hawaii-based effort accounted for nearly all effort recorded in the $\mathrm{CW}$ region; there was little to no competition from international fisheries. For the grid cells in the SW region with Hawaii-based fishing effort, international fisheries' effort was roughly equal to the effort of the Hawaii-based fishery. However, the ratio of Hawaii-based effort to international effort has increased steadily in the first quarter of each year over the years studied. For grid cells in the NW region with Hawaii-based fishing effort, there was little competition from international fisheries during the second and third quarters. In the first and fourth quarters, the ratio of Hawaii-based fishing effort to international effort has increased over the past decade, and the efforts of the 2 groups are now roughly equal. With the exception of the first and fourth quarters during the first 5 years of the time series, there was virtually no international fishing effort in the NE region.

\section{Oceanographic variability}

Spatial variability A great deal of spatial variability across the fishing grounds was observed in the median depth and vertical extent of the preferred thermal habitat of bigeye tuna $\left(8-14^{\circ} \mathrm{C}\right)$ (Fig. 1B). Median thermal habitat depth was at its maximum in the $\mathrm{CW}$ region, about $350-400 \mathrm{~m}$ below the surface, and it was shallowest in the NE region where it occurred within about $300 \mathrm{~m}$ of the surface. In the SW and NW regions, median thermal habitat depth ranged from $400 \mathrm{~m}$ to the surface at the northernmost latitudes. The full vertical extent of preferred thermal habitat of bigeye tuna also varied by region (Suppl. Fig. 3). The extent of this habitat was greatest in the SW and NW regions (depth: 200-450 m), least in the CW region (depth: 300-425 


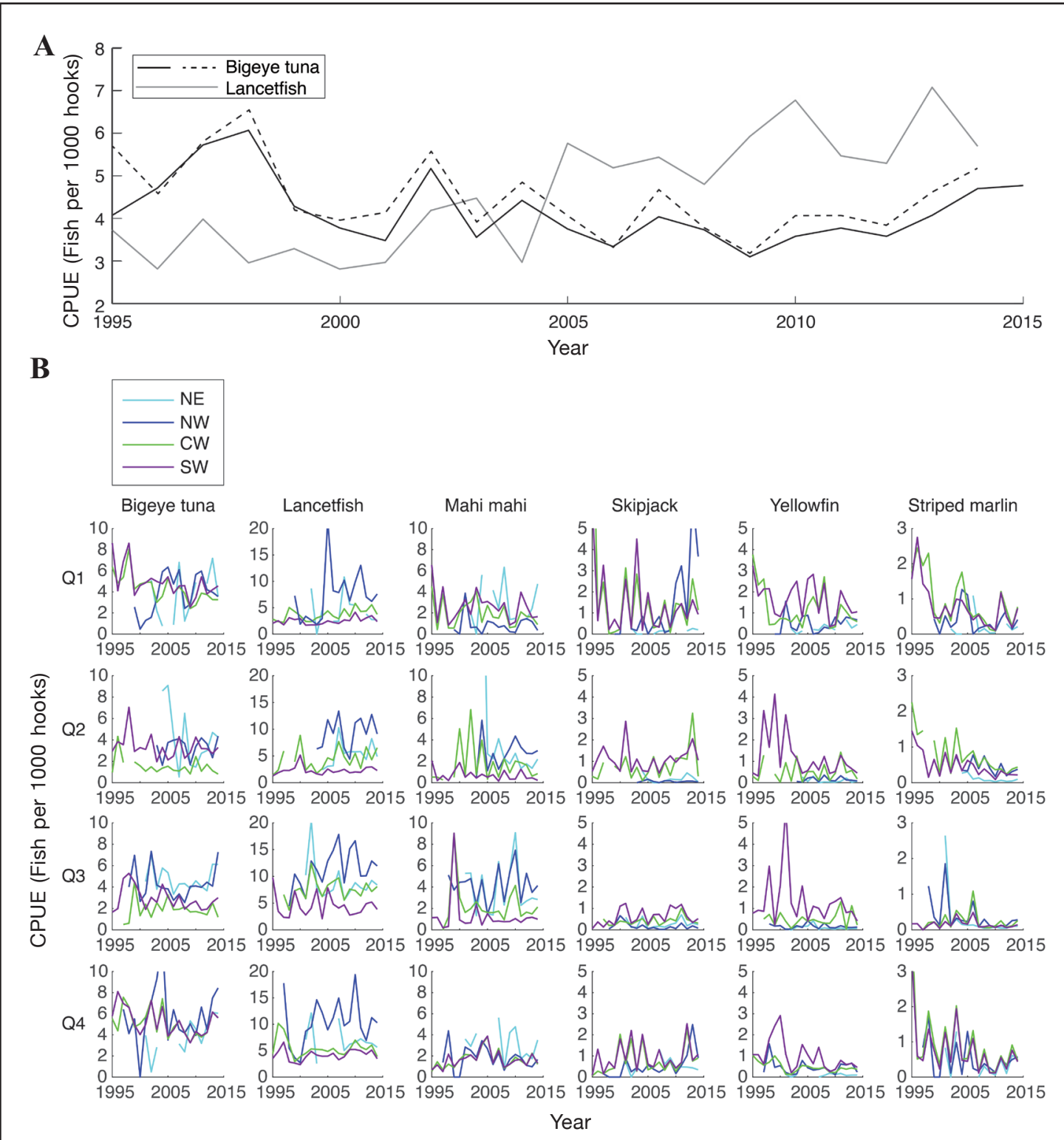

Figure 3

(A) Annual catch per unit of effort (CPUE) for bigeye tuna (Thunnus obesus; black lines) and longnose lancetfish (Alepisaurus ferox; gray line) for the Hawaii-based longline fishery from 1995 through 2015. The CPUE for bigeye tuna was calculated from both logbook records (solid black line), which are complete through 2015, and observer records (dashed black line), which are complete through 2014. The CPUE of longnose lancetfish was calculated from observer records. (B) Quarterly and regional CPUE, based on observer data, of bigeye tuna; longnose lancetfish; dolphinfish (Coryphaena hippurus), also known as mahi mahi; skipjack tuna (Katsuwonus pelamis); yellowfin tuna (Thunnus albacares); and striped marlin (Kajikia audax). Note that the scales of the y-axes vary by species.

$\mathrm{m}$ ), and shallowest in the NE region (depth: 200-350 $\mathrm{m})$.

Across the CW and NW regions, as well as much of the NE region, the depth of the oxygen-concentration threshold $(1.0 \mathrm{~mL} / \mathrm{L})$ for bigeye tuna was below $500 \mathrm{~m}$. In the SW region, this threshold was shallowest along $10^{\circ} \mathrm{N}$ (depth: 100-200 m) and progressed to depths below $500 \mathrm{~m}$ at the meridional extremes of the region.
The oxygen-concentration threshold for bigeye tuna was shallowest in the $\mathrm{SE}$ region, generally above 500 $\mathrm{m}$ and above $100 \mathrm{~m}$ along $10^{\circ} \mathrm{N}$ (Fig. 1B).

Temporal variability Across all grid cells where fishing occurred at some point during the time series, the median depth of preferred thermal habitat for bigeye tuna shoaled at a rate of $0.55-0.71 \mathrm{~m} /$ year, or by $12-15 \mathrm{~m}$ 


\begin{tabular}{|c|c|c|c|c|c|}
\hline \multicolumn{6}{|c|}{$\begin{array}{l}\text { Significant linear trends }(P<0.05) \text { in the median depth of the preferred thermal habitat of } \\
\text { bigeye tuna (Thunnus obesus }\left(8-14{ }^{\circ} \mathrm{C}\right) \text { based on logbook records of the Hawaii-based longline } \\
\text { fishery and ocean temperatures obtained from the Global Ocean Data Assimilation System } \\
\text { for } 1995 \text { through } 2015 \text {. These records were transformed into a grid, and the values in this } \\
\text { table were determined by using all grid cells with fishing effort at any time (any effort) and } \\
\text { by weighting grid cells by total quarterly effort (effort-weighted). A dash denotes the lack of a } \\
\text { significant trend. Each trend value is followed by the depth for } 2005 \text { from the linear regression } \\
\text { or, in the absence of a significant trend, by the mean depth of the time series. Results are pre- } \\
\text { sented for the full fishing ground, as well as for the northeast (NE), northwest (NW), central } \\
\text { west }(\mathrm{CW}) \text {, and southwest (SW) regions individually. }\end{array}$} \\
\hline \multirow[b]{2}{*}{ Region } & \multirow[b]{2}{*}{ Quarter } & \multicolumn{2}{|c|}{ Any effort } & \multicolumn{2}{|c|}{ Effort-weighted } \\
\hline & & Trend (m/y) & Depth (m) & Trend (m/y) & Depth (m) \\
\hline \multirow[t]{4}{*}{$\mathrm{NE}$} & Q1 & -1.36 & 255.46 & - & 302.59 \\
\hline & Q2 & -1.38 & 256.66 & - & 301.29 \\
\hline & Q3 & -1.17 & 254.00 & -2.64 & 291.71 \\
\hline & Q4 & -0.96 & 251.55 & - & 292.45 \\
\hline \multirow[t]{4}{*}{ NW } & Q1 & - & 264.21 & - & 346.42 \\
\hline & Q2 & - & 263.20 & -3.49 & 328.70 \\
\hline & Q3 & - & 262.85 & -3.69 & 290.24 \\
\hline & Q4 & - & 262.92 & -1.71 & 336.40 \\
\hline \multirow[t]{4}{*}{$\mathrm{CW}$} & $\mathrm{Q} 1$ & -1.52 & 367.35 & -0.85 & 358.42 \\
\hline & Q2 & -1.64 & 369.48 & -1.15 & 357.56 \\
\hline & Q3 & -1.76 & 365.06 & -1.63 & 352.98 \\
\hline & Q4 & -1.75 & 361.89 & -2.07 & 348.46 \\
\hline \multirow[t]{4}{*}{ SW } & Q1 & - & 265.83 & - & 292.62 \\
\hline & Q2 & - & 265.43 & -1.47 & 292.82 \\
\hline & Q3 & -0.48 & 266.78 & - & 302.72 \\
\hline & Q4 & -0.69 & 264.76 & -2.14 & 320.98 \\
\hline \multirow[t]{4}{*}{ Full fishing ground } & $\mathrm{Q} 1$ & -0.55 & 272.21 & - & 319.58 \\
\hline & Q2 & -0.71 & 272.67 & -1.78 & 303.25 \\
\hline & Q3 & -0.63 & 271.92 & -3.11 & 300.54 \\
\hline & Q4 & -0.70 & 269.91 & -2.23 & 336.08 \\
\hline
\end{tabular}

overall, shoaling from roughly 280 to $265 \mathrm{~m}$ between 1995 and 2015 (Table 1). Shoaling was significant and greater when the depths of these temperatures were weighted by total quarterly effort $(1.78-3.11 \mathrm{~m} /$ year or 37-65 $\mathrm{m}$ overall in the second-fourth quarters, shoaling from depths of 320-340 m to depths of 270-315 m over the course of the study period; Table 1). Significant shoaling within each region is presented in Table 1.

We lack sufficient data to examine variability in oxygen concentration over time. However, given that the oxygen-concentration threshold of bigeye tuna was found below $500 \mathrm{~m}$ across much of the area where the fishery operates, it is unlikely that low oxygen concentrations affected bigeye tuna in the study area.

\section{Catch variability}

Catch rates The annual catch rates of bigeye tuna declined until 2009, but have increased in subsequent years (Fig. 3A). Catch rates of longnose lancetfish, on the other hand, have increased over the past 2 decades, especially after 2004. For the past decade, catch rates of longnose lancetfish have exceeded those of bigeye tuna (Fig. 3A).

Quarterly catch rates of bigeye tuna and longnose lancetfish were considerably variable across the 4 regions of the fishery included in our analysis (Fig. 3B). The variability in catch rates of bigeye tuna was most striking in the third quarter, when the rates were notably higher in the NW and NE regions than in the SW and CW regions. Catch rates of longnose lancetfish were highest in the NW region and lowest in the SW region throughout the year. The quarterly and regional catch rates of mahi mahi, skipjack tuna (Katsuwonus pelamis), yellowfin tuna, and striped marlin are also presented in Figure 3B. The highest catch rates for these species, with the exception of mahi mahi, generally occurred in the SW and $\mathrm{CW}$ regions.

Catch composition The contribution of bigeye tuna to total catch varied by both quarter and region as did 


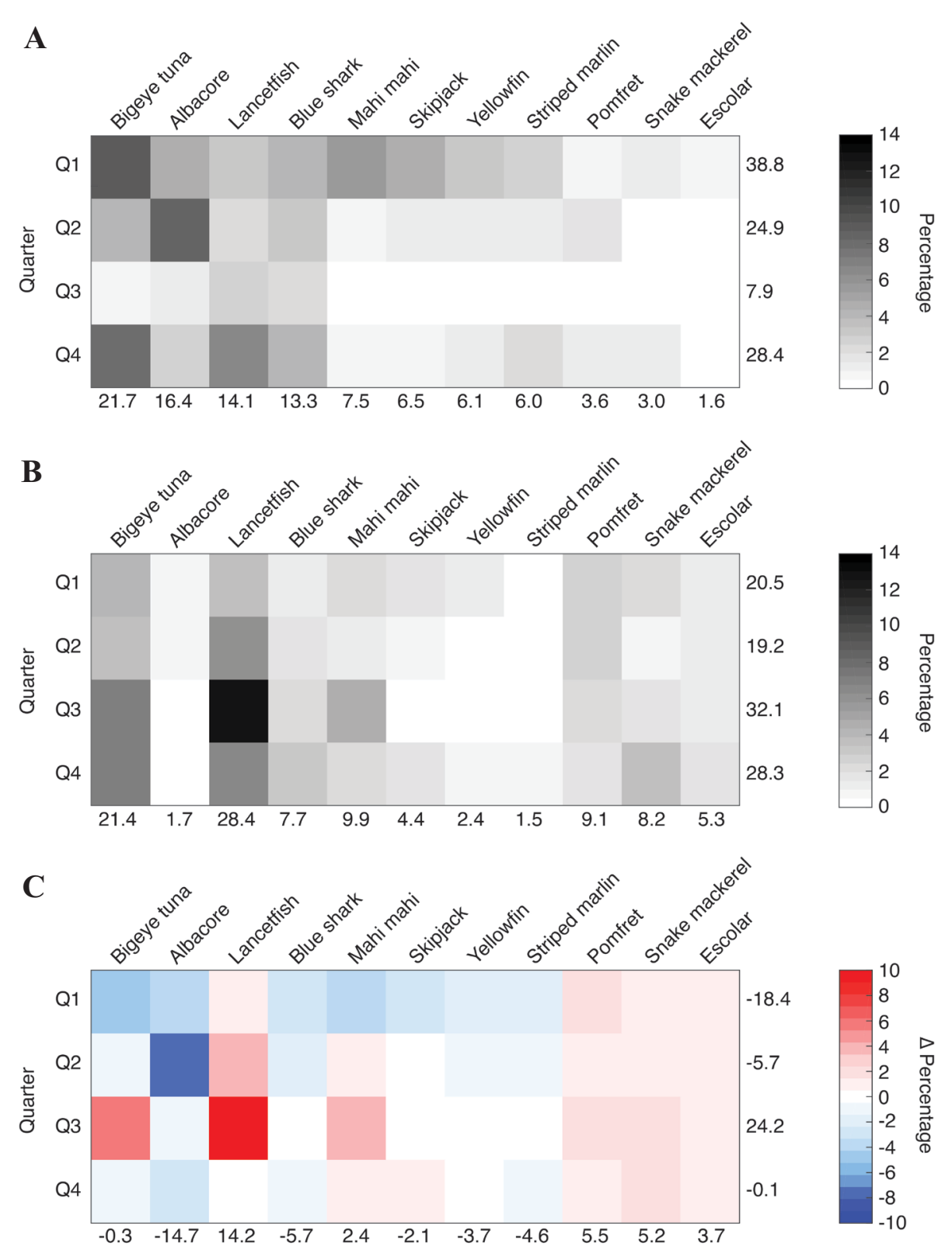

Figure 4

The mean percentages of total annual catch of the Hawaii-based longline fishery to which 11 species contributed each quarter, shaded for (A) the beginning (1995-1997) and (B) the end (2012-2014) of the time series of observer data, and (C) the differences between these percentages. The species were the following: bigeye tuna (Thunnus obesus); albacore (Thunnus alalunga); longnose lancetfish (Alepisaurus ferox); blue shark (Prionace glauca); dolphinfish (Coryphaena hippurus), also known as mahi mahi; skipjack tuna (Katsuwonus pelamis); yellowfin tuna (Thunnus albacares); striped marlin (Kajikia audax); sickle pomfret (Taractichthys steindachneri); snake mackerel (Gempylus serpens); and escolar (Lepidocybium flavobrunneum). In graphs A and $\mathrm{B}$, the total annual contribution of each species is listed below each column, and the total annual contribution from each quarter is listed along the right-hand side of each row. In graph $\mathrm{C}$, the difference in total annual contribution is listed below each column and along each row. 
the proportion of catch that was discarded (Suppl. Fig. 4). In general, bigeye tuna composed nearly $20 \%$ of the total catch, although their contribution ranged from as low as $8 \%$ (CW region, second and third quarter averages) to over $21 \%$ (CW and SW regions, fourth quarter averages). Discard rates had more variability; the lowest rates occurred in the SW region in the first and second quarters ( $<30 \%$ on average), and the highest rates in the third and fourth quarters across all regions (40-55\% on average).

In looking at catch composition, we found that each of the 11 species in Figure 4 accounted for at least 5\% of the total annual catch at some point in the time series. Their contribution to total catch is broken down in that figure by quarter for the beginning (Fig. 4A) and end (Fig. 4B) of the time series. These distributions indicate that the seasonal timing of catch of bigeye tuna shifted from the first and fourth quarters to the third and fourth quarters, but that the overall contribution of this species to the annual catch changed little. Conversely, the contribution of longnose lancetfish to total annual catch increased by about $14 \%$, primarily in the third quarter. The proportion of blue shark (Prionace glauca), yellowfin tuna, and striped marlin in total annual catch declined by $4-6 \%$, whereas the proportion of sickle pomfret, snake mackerel, and escolar (Lepidocybium flavobrunneum) rose by 4-6\% over the time series.

\section{Discussion}

Over the 21-year period examined in this study, the fishing effort of the Hawaii-based longline fishery increased more than 5-fold. A growing proportion of this effort occurred in the NE region of the fishing grounds, particularly during the third quarter of the year. The GODAS reanalysis and WOA13 data indicate that oceanographic conditions are favorable for bigeye tuna across much of the fishery's footprint. Although increasing effort should correlate with the desire of fishermen to catch more fish, the shift in the seasonal and spatial deployment of effort raises several biologically pertinent questions. Why did the fishery expand its spatial footprint, as opposed to it simply setting more hooks across the CW and SW regions? Why did it expand, primarily, into the NE region and only during the third quarter of the year?

The expansion of the fishery into the NE region during the third quarter is likely the result of several factors. One possibility is that the $\mathrm{CW}$ and $\mathrm{SW}$ regions were already supporting maximum effort. Effort was rather stable in these regions after about 2004 (Fig. 2), and previous work has documented that the catch rates of large, high-trophic-level, commercially valuable fish were declining in these waters as a result of increased fishing effort (Polovina et al., 2009; Polovina and Woodworth-Jefcoats, 2013). Furthermore, competition from international fisheries may have precluded additional Hawaii-based effort in the SW region. In the NW and $\mathrm{NE}$ regions, on the other hand, there was comparably little Hawaii-based effort and little to no competition from international fisheries.

Less than $10 \%$ of the total annual catch was caught during the third quarter of the year at the beginning of the time series (Fig. 4). Furthermore, in the CW and SW regions, target catch rates were lowest $(9 \%$ and $14 \%$ on average, respectively) and discard rates highest (56\% and $44 \%$ on average, respectively; Suppl. Fig. 4) during the third quarter, possibly explaining why fishermen have been willing to change fishing locations. These low target catch rates may also explain why effort was lowest in the third quarter at the beginning of the time series, and why, unlike in other quarters, effort was not concentrated in a specific region (before the focus of the fishery on the NE region).

Considering the distribution of fishing effort together with catch rates, we found that trends in catch rates are strongly correlated with the shift in the location of effort. Comparison of quarterly CPUE of bigeye tuna with the proportion of annual effort in each region and quarter indicates that the third-quarter CPUE of bigeye tuna was strongly correlated with the proportion of effort in the NE region (coefficient of correlation $[r]=0.66$ ) and negatively correlated with third quarter effort in the $\mathrm{CW}$ and $\mathrm{SW}$ regions $(r=-0.56$ and -0.46 , respectively). No other significant correlations were found $(P<0.5)$. Given the above correlations and the trends in catch composition, we conclude that the fishery reaction was a response to low catch rates for the target species in the $\mathrm{CW}$ and $\mathrm{SW}$ regions during the third quarter. The NE region proved to be a particularly effective fishing ground with high catch rates of target species, relatively low discard rates, and with little competition from international fishing fleets. As a result, a large portion of annual catch of bigeye tuna occurred in the third quarter by the end of the time series (Fig. 4).

Although the movement of the fishery toward the NE region was greatest in the third quarter, the fishery does occur in this region throughout the year, although to a lesser degree (Fig. 2). As discussed above, catch rates of target species in the $\mathrm{SW}$ and $\mathrm{CW}$ regions were generally higher during the rest of the year, possibly explaining why there was less fleet movement outside the third quarter.

\section{The role of oceanographic variability in fishery expansion}

The enhanced fishery yield in the NE region can be explained by the oceanographic conditions of the region. It has the largest area in which preferred thermal habitat of bigeye tuna closely overlaps vertically with both deep-set hooks (100-400 m) and with waters that have suitable oxygen concentrations (>1.0 mL/L; Fig. 1B). The time series of the depths of preferred thermal habitat shows that in the NE region, the preferred daytime habitat of bigeye tuna was consistently and completely within the depth range of deep-set hooks (Suppl. Fig. 3). Oceanographic variability also explains why the fishery did not expand into the SE region. 
This region encompasses the oxygen minimum zone of the eastern tropical Pacific Ocean. Across much of the $\mathrm{SE}$ region, the oxygen-concentration threshold of $1.0 \mathrm{~mL} / \mathrm{L}$ occurred at depths shallower than the depths of both the preferred thermal habitat of bigeye tuna and the depths of deep-set gear (Fig. 1B), rendering it poor habitat for bigeye tuna and poor longline fishing grounds.

Effort-weighted trends in the depth of preferred habitat of bigeye tuna indicate that the fishery has moved into the more favorable oceanographic conditions of the $\mathrm{NE}$ region. At the beginning of the time series, the fishery was operating largely in waters where the median depth of preferred thermal habitat for bigeye tuna was roughly 320-340 m below the surface. However, by the end of the time series, the fishery was operating in waters where the median depth of preferred thermal habitat was 270-315 m below the surface and more closely aligned with the median depth of deep-set gear (250 m; Boggs, 1992; Bigelow et al., 2006). These trends in depth weighted by total quarterly effort indicate that fishermen were targeting regions where either preferred thermal habitat was more closely aligned with their gear or thermal habitat shoaling was greatest or possibly employing a combination of these 2 tactics. Across the entire fishing ground, the preferred thermal habitat of bigeye tuna shoaled by only about $12-15 \mathrm{~m}$. Yet, when weighted by quarterly effort, the shoaling increased to roughly $37-65 \mathrm{~m}$. Without information on depth of capture, it is difficult to determine the degree to which this shoaling actually influenced the fishery yield. However, given the vertical distributions of both deep-set gear and preferred daytime thermal habitat of bigeye tuna, shoaling could increase the degree to which these distributions overlap and could compress the total vertical habitat that bigeye tuna occupy. Both scenarios should increase the catchability of bigeye tuna, and in turn, fishery yield.

\section{Effects of fishery expansion on catch composition}

During the period studied, the spatial expansion and seasonal shift of the fishery influenced the seasonal timing of both the catch and catch composition. Although the primary target species, bigeye tuna, consistently was about $20 \%$ of the total annual catch, the bulk of the annual catch shifted from the first and fourth quarters to the third and fourth quarters. A combination of factors could have contributed to this shift. The foremost factor was the increase during the third quarter in effort deployed in the NE region (Fig. 2 ), where catch rates of bigeye tuna were consistently high over time (Fig. 3B). Additionally, by the end of the period examined, less effort was deployed in the $\mathrm{SW}$ region in the first quarter than in the $\mathrm{CW}$ region during the fourth quarter (Fig. 2). First quarter catch rates of bigeye tuna in the SW region declined over the past 2 decades (Fig. 3B), whereas fourth quarter catch rates of bigeye tuna in the $\mathrm{CW}$ region remained consistently high. In summary, by 2015, the fishery deployed most of its effort in the regions and during the quarters when catch rates of bigeye tuna were highest. It is interesting to note that these regions are also those where preferred thermal habitat for bigeye tuna completely overlaps with deep-set gear (NE region) and where preferred thermal habitat for bigeye tuna is most compressed (CW region) (Suppl. Fig. 3).

It is possible that the shift in time and place of the bulk of bigeye tuna catch each year can be attributed to changes in fishing gear, although we found no evidence that this shift was the cause. Using the number of hooks per float as a proxy for hook depth, we found no significant differences between gear set in the SW region during the first quarter, in the $\mathrm{NE}$ region during the third quarter, and in the $\mathrm{CW}$ region during the fourth quarter (5\% significance level, Wilcoxon-MannWhitney rank-sum tests).

The shift in the annual timing of catch of bigeye tuna could also be attributed to fish movement or changes in population dynamics. Stock assessments from both fishing convention areas (west of $150^{\circ} \mathrm{W}$, WCPFC, Harley et al., 2014; east of $150^{\circ} \mathrm{W}$, IATTC, Aires-da-Silva and Maunder, 2015), along with tagging data (Schaefer et al., 2015), indicate that there is extensive zonal movement by bigeye tuna. At low latitudes (e.g., $15^{\circ} \mathrm{S}-$ $15^{\circ} \mathrm{N}$ ), there is more eastward movement than westward movement (Aires-da-Silva and Maunder, 2015; Schaefer et al., 2015). However, a lack of tagging data for areas farther north makes it difficult to determine whether bigeye tuna make the same directional movement in our study area. If they do, the high catch rates in the $\mathrm{NE}$ region noted in our study may have been fueled in part by fish moving into the region. The role of population dynamics is also unclear. Although it is likely that large-scale population dynamics affect interannual changes in CPUE of bigeye tuna (Harley et al., 2014; Aires-da-Silva and Maunder, 2015), size structure (and presumably age structure) of bigeye tuna was fairly consistent across the fishing ground (Suppl. Fig. 5), echoing earlier work (Kume, 1969).

For other commercially valuable species, such as yellowfin tuna and striped marlin, the spatial shift in effort exacerbated declining catch rates. Although CPUEs for both species declined across the fishing grounds, catch rates for these species were greatest in the SW and CW regions despite the movement of the fishery away from these regions (Fig. 3B). Catch rates for skipjack tuna, although not declining, were generally highest in the SW and CW regions (Fig. 3B). Therefore, the fishery's changing footprint likely contributed to an overall decline in the contribution of skipjack tuna to total annual catch (Fig. 4).

Discard rates also were influenced by the spatiotemporal shift in effort. In the core region of the fishery $\left(12-27^{\circ} \mathrm{N}\right)$, rising discard rates were linked to increased fishing effort (Polovina and Woodworth-Jefcoats, 2013). At the same time, catch rates of longnose lancetfish in particular rose as a result of the fishery's northward expansion and increased focus on the third 
quarter. Catch rates of longnose lancetfish were not only highest in the NW region but were also highest within-region in the third quarter (Fig. 3B). Therefore, the fishery deployed more effort in a region where longnose lancetfish were more commonly caught and during the season when catch rates were highest. As a result, catch of longnose lancetfish, all of which was discarded, exceeded the catch of target species for the last decade of the study period (Fig. 3A). The same spatiotemporal shift in effort also explains the change in the contribution of mahi mahi to annual catch (Figs. 3B and 4), although mahi mahi are retained by the fishery and sold.

As with bigeye tuna, it is possible that both fish movement and population dynamics could have influenced changes in total composition of the catch. Tagging data and stock assessments are lacking for many of the species caught by the Hawaii-based longline fishery, especially the noncommercial species. Future research on the seasonal timing, location, and size structure of this catch may provide insight into such changes.

When using observer data to determine catch composition, as we did, there is a possibility that observer error could influence results. Such errors in the reporting of rare or cryptic species have been noted for individual longline sets and can influence results at fine spatiotemporal resolutions (e.g., months and single geographic degrees) and when observer coverage is low (Walsh et al., 2002; Walsh et al., 2005). However, it is not clear that such errors would be distinguishable when observer data are aggregated more broadly, such as on a quarterly and regional basis. Additionally, our results indicate strong agreement between data collected from independent scientific observers and data reported in commercial vessel logbooks for catch rates of bigeye tuna (Fig. 3A) and, therefore, consistent species identification of target species. The observed increase in catch of longnose lancetfish is corroborated by the regional expansion of the fishery: catch rates of longnose lancetfish were much higher in the NW region than elsewhere (Fig. 3B), and, in the early years of our study, the fishery was not operating in the NW region (Fig. 2A). Therefore, we conclude that the impacts of fishery expansion on catch composition are robust.

\section{A look ahead}

We have detailed how both fishery expansion and oceanographic variability have influenced catch of the Hawaii-based longline fishery. In particular, we found that the fishery has expanded into a region that has proven to be an efficient fishing ground by virtue of its local oceanography. With this perspective on past catch, can CPUEs continue to rise into the future? The results of previous work indicate that sustained increases in fishing effort drive down the abundance of large, high-trophic-level fish, such as those targeted by the Hawaii-based longline fishery (Ward and Myers, 2005b; Polovina et al., 2009; Polovina and Woodworth-Jefcoats,
2013). We also note that, although bigeye tuna are not considered to be subject to overfishing in the $\mathrm{NE}$ region (Aires-da-Silva and Maunder, 2015), overfishing of bigeye tuna has been documented to be occurring in the 3 western regions (Harley et al., 2014). This disparity creates the potential for further eastward displacement of fishing effort (both Hawaii-based and international) and for hastening removals of bigeye tuna. Therefore, it is possible that catch rates in the NE region eventually will diminish as have the catch rates in the SW and $\mathrm{CW}$ regions over the past 20 years.

Another change that will affect the fishery in coming years is the recent expansion of the Papahānaumokuākea Marine National Monument. In August 2016, the monument boundaries were expanded to encompass the full U. S. Exclusive Economic Zone west of $163^{\circ} \mathrm{W}$, moving the boundaries an additional $150 \mathrm{~nm}$ from land (Federal Register, 2016). This expansion bars commercial fishing over a portion of the fishing grounds and has the greatest effect on the $\mathrm{CW}$ region. On average, $21 \%$ of the effort in the $\mathrm{CW}$ region in the fourth quarter (when fishing effort in this region is the greatest) and $25 \%$ of the bigeye tuna caught in the $\mathrm{CW}$ region during the fourth quarter are from waters that will now be off limits to the fishery. It is uncertain how the fishery will adjust, possibly by simply relocating fourth quarter effort outside the monument area or by shifting the allocation of that effort to another quarter or region.

Finally, climate change can be expected to affect the Hawaii-based longline fishery in a number of ways, potentially driving productive fishing grounds even farther from Hawaii. As ocean temperatures continue to rise, the preferred thermal habitat of bigeye tuna will be displaced northward (Lehodey et al., 2010; Bopp et al., 2013; Woodworth-Jefcoats et al., 2017). Additionally, the oxygen minimum zone that covers much of the SE region (Fig. 1B) has expanded over the past 50 years (Stramma et al., 2008). Although climate projections of further expansion are mixed (Stramma et al., 2008; Bopp et al., 2013; Cabré et al., 2015), continued expansion potentially would encroach on the NE region and render a larger portion of the SW region inhospitable to bigeye tuna.

We have shown how movement of the Hawaii-based longline fishery, particularly its seasonally focused expansion to the NE region, has helped shape the composition, magnitude, and seasonal timing of its catch. This information, together with previous studies of the effect of the Hawaii-based fishery on the ecosystem, as well as future climate projections and socioeconomic data (such as trip cost and catch value), has the potential to help guide future fishery management actions. For example, recent increases in CPUE of bigeye tuna can be placed in the context of the high catch rates the fishery saw in the late 1990s. Climate models could be used to project future changes in habitat of bigeye tuna. Additionally, the effect of the continued expansion of the fishery away from Hawaii can be assessed in relation to other factors, such as future fuel prices 
for fishing vessels. Such context and analyses can help fishery managers ensure that the Hawaii-based longline fishery remains both ecologically and financially sustainable.

\section{Acknowledgments}

The authors are grateful for insight from E. Portner, C. Boggs, M. Donahue, A. Timmermann, and K. Edwards that greatly improved this manuscript. We thank the scientific observers of the Pacific Islands Region for their ongoing collection of longline fishery data. We also thank A. Tomita for help in formatting international fisheries data. This article is contribution 10356 of the School of Ocean and Earth Science and Technology, University of Hawaii at Manoa.

\section{Literature cited}

Aires-da-Silva, A., and M. N. Maunder.

2015. Status of bigeye tuna in the eastern Pacific Ocean in 2014 and outlook for the future. Inter-American Tropical Tuna Commission Stock Assess. Rep. 16, 13 p. [Available from website, accessed October 2016.]

Bigelow, K., M. K. Musyl, F. Poisson, and P. Kleiber.

2006. Pelagic longline gear depth and shoaling. Fish. Res. 77:173-183. Article

Boggs, C. H.

1992 Depth, capture time, and hooked longevity of longline-caught pelagic fish: timing bites of fish with chips. Fish. Bull. 90:642-658.

Bopp, L., L. Resplandy, J. C. Orr, S. C. Doney, J. P. Dunne, M. Gehlen, P. Halloran, C. Heinze, T. Ilyina, R. Séférian, et al. 2013. Multiple stressors of ocean ecosystems in the $21^{\text {st }}$ century: projections with CMIP5 models. Biogeosciences 10:6225-6245. Article

Cabré, A., I. Marinov, R. Bernardello, and D. Bianchi.

2015. Oxygen minimum zones in the tropical Pacific across CMIP5 models: mean state differences and climate change trends. Biogeosciences 12:5429-5454. Article

Cox, S. P., T. E. Essington, J. F. Kitchell, S. J. D. Martell, C. J. Walters, C. Boggs, and I. Kaplan.

2002. Reconstructing ecosystem dynamics in the central Pacific Ocean, 1952-1998. II. A preliminary assessment of the trophic impacts of fishing and effects on tuna dynamics. Can. J. Fish. Aquat. Sci. 59:1736-1747. Article

Federal Register.

2016 Papah naumoku kea Marine National Monument expansion. Fed. Reg. 81:60227-60234. GPO, Washington, D.C. Available at website

Garcia, H. E., R. A. Locarnini, T. P. Boyer, J. I. Antonov, A. V. Mishonov, O. K. Baranova, M. M. Zweng, J. R. Reagan, and D. R. Johnson.

2013. World ocean atlas 2013. Volume 3: dissolved oxygen, apparent oxygen utilization, and oxygen saturation. NOAA Atlas NESDIS 75, $27 \mathrm{p}$.

Gilman, E., M. Chaloupka, A. Read, P. Dalzell, J. Holetschek, and C. Curtice.

2012. Hawaii longline tuna fishery temporal trends in standardized catch rates and length distributions and effects on pelagic and seamount ecosystems. Aquat. Conserv. 22:446-488. Article

Harley, S., N. Davies, J. Hampton, and S. McKechnie.

2014. Stock assessment of bigeye tuna in the western and central Pacific Ocean. West. Cent. Pac. Fish. Comm. WCPFC-SC10-2014/SA-WP-01, 115 p. [Available from website, accessed October 2016.]

Howell, E. A., D. R. Hawn, and J. J. Polovina.

2010. Spatiotemporal variability in bigeye tuna (Thunnus obesus) dive behavior in the central North Pacific Ocean. Prog. Oceanogr. 86:81-93. Article

Kitchell, J. F., T. E. Essington, C. H. Boggs, D. E. Schindler, and C. J. Walters.

2002. The role of sharks and longline fisheries in a pelagic ecosystem of the central Pacific. Ecosystems 5:202-216. Article

Kume, S.

1969. Ecological studies on bigeye tuna-V: A critical review on distribution, size composition and stock structure of bigeye tuna in the North Pacific Ocean (north of $\left.16^{\circ} \mathrm{N}\right)$. Bull. Far Seas Fish. Res. Lab. 1:57-75.

Lehodey, P., I. Senina, J. Sibert, L. Bopp, B. Calmettes, J. Hampton, and R. Murtugudde.

2010. Preliminary forecasts of Pacific bigeye tuna population trends under the A2 IPCC scenario. Prog. Oceanogr. 86:302-315. Article

Polovina, J. J., and P. A. Woodworth-Jefcoats.

2013. Fishery-induced changes in the subtropical Pacific pelagic Ecosystem size structure: observations and theory. PLoS ONE 8(4):e62341. Article

Polovina, J. J., M. Abecassis, E. A. Howell, and P. Woodworth. 2009. Increases in the relative abundance of mid-trophic level fishes concurrent with declines in apex predators in the subtropical North Pacific, 1996-2006. Fish. Bull. 107:523-531.

Saha, S., S. Nadiga, C. Thiaw, J. Wang, W. Wang, Q. Zhang, H. M. Van den Dool, H.-L. Pan, S. Moorthi, D. Behringer, et al.

2006. The NCEP Climate Forecast System. J. Clim. 19:3483-3517. Article

Schaefer, K., D. Fuller, J. Hampton, S. Caillot, B. Leroy, and D. Itano.

2015 Movements, dispersion, and mixing of bigeye tuna (Thunnus obesus) tagged and released in the equatorial Central Pacific Ocean, with conventional and archival tags. Fish. Res. 161:336-355. Article

Sibert, J., J. Hampton, P. Kleiber, and M. Maunder.

2006. Biomass, size, and trophic status of top predators in the Pacific Ocean. Science 314:1773-1776. Article

Stramma, L., G. C. Johnson, J. Sprintall, and V. Mohrholz.

2008. Expanding oxygen-minimum zones in the tropical oceans. Science 320:655-658. Article

Walsh, W. A., and J. Brodziak.

2015. Billfish CPUE standardization in the Hawaii longline fishery: model selection and multimodel inference. Fish. Res. 166:151-162. Article

Walsh, W. A., P. Kleiber, and M. McCracken.

2002. Comparison of logbook reports of incidental blue shark catch rates by Hawaii-based longline vessels to fishery observer data by application of a generalized additive model. Fish. Res. 58:79-94.

Walsh, W. A., R. Y. Ito, K. E. Kawamoto, and M. McCracken. 2005. Analysis of logbook accuracy for blue marlin (Mak- 
aira nigricans) in the Hawaii-based longline fishery with a generalized additive model and commercial sales data. Fish. Res. 75:175-192. Article

Ward, P., and R. A. Myers.

2005a. Inferring the depth distribution of catchability for pelagic fishes and correcting for variations in the depth of longline fishing gear. Can. J. Fish. Aquat. Sci. 62:1130-1142. Article 2005b. Shifts in open-ocean fish communities coinciding with the commencement of commercial fishing. Ecology 86:835-847. Article

Woodworth-Jefcoats, P. A., J. J. Polovina, and J. C. Drazen. 2017. Climate change is projected to reduce carrying capacity and redistribute species richness in North $\mathrm{Pa}$ cific pelagic marine ecosystems. Global Change Biol. 23:1000-1008. Article 